Роговський І. Л.

\title{
УДК 631.04.001
}

\section{АНАЛІЗ ВТРАТ ЗЕРНОВОГО ЗБІЖЖЯ КЛАСИЧНИМ МОЛОТИЛЬНО- СЕПАРУВАЛЬНИМ ПРИСТРОЕМ ЗЕРНОЗБИРАЛЬНОГО КОМБАЙНА}

І. Л. РОГОВСБКИЙ, доктор технічних наук, старший науковий співробітник, доцент кафедри технічного сервісу та інженерного менеджменту імені

\author{
М. П. Момотенка
}

https://orcid.org/0000-0002-6957-1616

\section{Національний університет біоресурсів і природокористування України}

E-mail: rogovskii@nubip.edu.ua

https://doi.org/dopovidi2021.04.014

Анотація. На підставі аналізу більшості вітчизняних комбайнів встановлено, щзо вони мають традиційну схему молотильно-сепаруючого пристрою, щзо включає один або два послідовно розташованих бильних молотильних апаратів і клавішний соломотряс. Конструкиія підбарабанням із прутків із поперечними пластинами передбачає, насамперед, інтенсифікачію процесу вимолотила зерна. Зернові культури вимолочується легко, тому немає необхідності в інтенсифікації вимолотила. Наприклад, за збирання зернозбиральних комбайном КЗС-9М «Славутич» за зазору на виході між молотильним барабаном $i$ підбарабанням 18 мм $i$ частоті обертання молотильного барабана 450 хв$^{-1}$ втрати недомолоту були відсутні $y$ всіх дослідах. У изьому разі поперечні пластини підбарабання $\epsilon$ перешкодою для перемішення обмолочуваної маси в молотильно-сепарувальний пристрій, утворюючи за кожною планкою мертвий простір, де скупчується дрібна складова рослинної маси.

Якість роботи молотильно-сепарувального пристрою зернозбирального комбайна визначали за коефіцієнтами недомолоту, сепарації, дроблення й засміченості зерна, яке надійшло на очистку.

Пошкодження зерна під час обмолоту в молотаризі відбувається в основному завдяки впливу окружний лінійної швидкості молотильного барабана $\check{u}$ зазору між молотильним барабаном $i$ підбарабанням. Тому зазор $y$ молотильного просторі $\epsilon$ змінним $і$ змінюється в бік зменшення від входу рослинної маси в молотильний пристрій до його виходу. Узагальнюючим параметром, ми використовував зазор у молотильного просторі на виході $з$ молотарки. У зв'язку з цимм, початок випробувань був за частоти обертання барабана 450 хв ${ }^{-1}$. Під час випробувань було встановлено, щзо найбільший вплив на пошкодження зерна надає колова лінійна швидкість молотильного барабана. Так, за збільшення частоти обертання барабана на $100 x^{-1}$ з 450 до $550 \mathrm{xb}^{-1}$, пошкодження збільшувалися з 1,5\% до 5,5\%, тобто практично в 4 рази.

Ключові слова: зерно, комбайн, втрати, модель, сепарація, пристрій

Актуальність. Аналіз даних багаторічних досліджень [14] показує, що застосування обробкою технологій 3 на стаціонарі 
Роговський І. Л.

виправдано тільки для збирання зернових [6] i деяких багаторічних трав [10] в певному поєднанні 3 комбайнового технологією i головним чином там, де зернозбиральні комбайни працюють незадовільно [3]. Насамперед варто іiі впровадити на збиранні зернофуражних культур, низьковрожайних (до 15 ц/га) i високоврожайних (понад 50 ц/га) хлібів [19]. Тому основною технологією збирання зернового збіжжя $\epsilon$ пряме комбайнування 3 передзбиральною десикацією посівів [8].

Більшість вітчизняних комбайнів мають традиційну схему молотильносепаруючого пристрою, що включає один або два послідовно розташованих бильних молотильних апаратів і клавішний соломотряс [16]. Майже 200-річним дослідженням раціональної конструкції молотарок для машинного обмолоту створені різноманітні конструкції молотильносепаруючого пристрою [5]. Конструкція робочого органу, уперше оформлена шотландцем Ендрю Мейклем в 1785 році у вигляді циліндричного барабана, i понині залишається незмінною. У цей час не знайдено принципово нових рішень процесу обмолоту й сепарації, що дає змогу істотно підвищити пропускну здатність без збільшення розмірів $\mathrm{i}$ маси робочих органів i машини загалом [9]. Водночас практично вже вичерпала можливість підвищення пропускної

Здатності зернозбиральних комбайнів через збільшення ширини молотарки, яка обмежена умовами транспортування зернозбирального комбайна колісними транспортними засобами [1]. Дослідження в основному ведуться в напрямі інтенсифікації процесів обмолоту або інтенсифікації всього робочого комбайна завдяки компонувальним та іншим конструкторським рішенням [12].

Як за кордоном, так і в Україні, досліджувався технологічний процес комбайна $з$ попередніми обмолотом у похилій камері [17]. Багатобітерний пристрій зменшує нерівномірність подачі маси в динаміці, підвищує пропускну здатність комбайна на 20$50 \%$ [11]. Однак розміщення в похилій камері молотильного й сепаруючих органів знижує надійність технологічного процесу [7]. Крім кількох дослідних зразків комбайнів, практичного застосування ці розробки не знайшли [13].

Напрям досліджень молотильних пристрій iз фігурним барабаном, забезпеченим зигзагоподібними бичами й декою 3 поздовжніми гребнями [2]. За такої форми бичів збільшується наведена подача для барабана за збереженні конструктивної ширини молотарки [18]. Завдяки цьому, пропускна здатність цього молотильносепаруючого пристрою на 50-60\% вище, ніж у того ж по ширині бильного апарату. У місці 3 тим 
Роговський І. Л.

відзначається менша, ніж у останнього, рівномірність розподілу обмолочують продукту, що, безумовно, призведе до збільшення втрат на не вимолочування [4].

Роторні молотильні пристрої впливають на масу, як ударом по колосу, так i протягуванням між поверхнями кожної пари роторів [12]. Але роторні молотильні пристрої на 25-32\% більш енергоємні, ніж барабанно-деків, й основний $\ddot{1 x}$ недолік полягає в тому, що вони погано виділяють вільне зерно 3 соломистої маси [3].

Тому вбачається актуальним змінити конструкцію молотильносепаруючого пристрою, щоб не змінювати процес сепарації. Усунути забивання й поліпшити очищення можна за допомогою підбарабання. Це можливо за виконання підбарабання у вигляді гладкої циліндричної сепаруючої поверхні, причому, всією сепаруючою поверхнею виконані наскрізні отвори довгастої форми, розташовані рядами різної спрямованості під кутом до напрямку руху маси.

Аналіз останніх досліджень та публікацій. Під час збирання легковимолочуваних, крупно-, легкотравмуючих культур, таких як зернові збільшують зазори між молотильним барабаном i підбарабанням, що веде до збільшення в ньому товщини шару обмолочуваної соломисто-зернової маси і знижує ефект самоочищення поверхні підбарабання [15]. Конструкція підбарабанням із прутків 3 поперечними пластинами передбачає, насамперед, інтенсифікацію процесу вимолотила зерна. Зернові культури вимолочується легко, тому немає необхідності в інтенсифікації вимолотила. Наприклад, під час збирання зернозбиральних комбайном КЗС-9М «Славутич» за зазору на виході між молотильним барабаном i підбарабанням 18 мм i частоті обертання молотильного барабана $450 \mathrm{xв}^{-1}$ втрати недомолоту були відсутні у всіх дослідах. У цьому разі поперечні пластини підбарабання € перешкодою для переміщення обмолочуваної маси в молотильносепарувальний пристрій, утворюючи за кожною планкою мертвий простір, де скупчується дрібна складова рослинної маси [11]. Така конструкція призводить до забивання сепаруючих отворів підбарабання саме за збільшених зазорах, що погіршує сепарацію зерна через них [8]. Через це збільшується завантаження соломовідокремлювача й у підсумку збільшуються втрати вільним зерном за молотаркою комбайном. Яке не пройшло через решітку підбарабання зерно піддається додатковим ударних впливів бичів, що так само підвищує ймовірність додаткового пошкодження зерна [19].

Відомо пристрій підбарабання конструкції Л. Н. Буркова, що містить поздовжні планки і поперечні прути, 
Роговський І. Л.

які встановлені по краях плоских зігнутих боковин на охоплення $5 \ldots 7^{\circ}$ симетрично 3 обох кінців, а інша частина підбарабання виконана у вигляді декількох валів, встановлених паралельно один одному в боковинах 3 можливістю обертання. Також відомо підбарабання молотильносепаруючого пристрою, що містить підбарабання, яке забезпечено додатковими поперечними планками 3 робочими крайками, виконаними 3 чергуючих прямолінійних ділянок, розташованих на одному рівні 3 симетричними криволінійними ділянками, спрямованими увігнутістю до осі поверхні, що обгинає робочі кромки основних планок [7]. Недоліками цих моделей є складність конструкції, і так само не усунення процесу забивання сепаруючих отворів підбарабання під час збирання зернових культур, що вимагають великих зазорів між барабаном і підбарабанням. Так само в них може відбуватися підвищена пошкоджуваність зерна під час обмолоту зернових культур.

Завдання інженерної моделі підвищення сепарації зерна крізь підбарабання. Технічний результат зниження втрат зерна i зменшення пошкодження зерна завдяки більш інтенсивного відводу його із зони впливу бичів молотильного барабана. Поставлена задача вирішується за рахунок того, що підбарабання молотильно-сепаруючого пристрою виконано у вигляді циліндричної поверхні, 3 радіусом кривизни дещо більшою, ніж радіус траєкторії руху бичів молотильного барабана, що за зміщення їх центрів дозволяє виконати молотильний зазор постійно зменшується від входу до виходу 3 молотильного простору [14]. Циліндрична поверхня підбарабання якою рухається рослинна маса гладка 3 наскрізними продовгуватими отворами, велика вісь яких розташована під деяким кутом вздовж напрямку руху маси [9]. Така форма i розташування отворів забезпечує сепарацію дрібного оберемка 3 вільним зерном в міру його утворення, так як проекція рухає зерна у напрямку його руху (дотична до його траєкторії) має мати, як можна менше перешкод 3 конструкторських елементів підбарабання [2]. Причому, чим більше зерно й більше радіус кривизни підбарабання, тим має бути більше довжина сепаруючих отворів. Конструкція підбарабання, виконана 3 листового матеріалу, забезпечує ефект самоочищення під час роботи, так як відсутні мертві зони молотильного простору, де за активного впливі бичів барабана не відбувається рух рослинної маси, що не дозволяє забивати сепарувальні отвори. Крім того, розташування довгастих отворів при чергуванні від ряду до ряда кутах напрямків більшою осі отворів до напрямку руху маси викликає поперечне коливання контактуючих 3 ними шарів рослин. Завдяки цьому інтенсифікується 
Роговський І. Л.

процес сепарації зерна, як через шари рослинної маси, так і через підбарабання [11].

На рис. 1 схематизовано молотильно-сепарувальний пристрій. Пропонований пристрій (рис. 1) складається 3 молотильного барабана 1 з бичами 2 підбарабання 3 г гладкою сепаруючої поверхнею, на якій виконані довгасті отвори 4, які розташовані рядами різної спрямованості під кутом до напрямку руху маси в пристрої. Працює

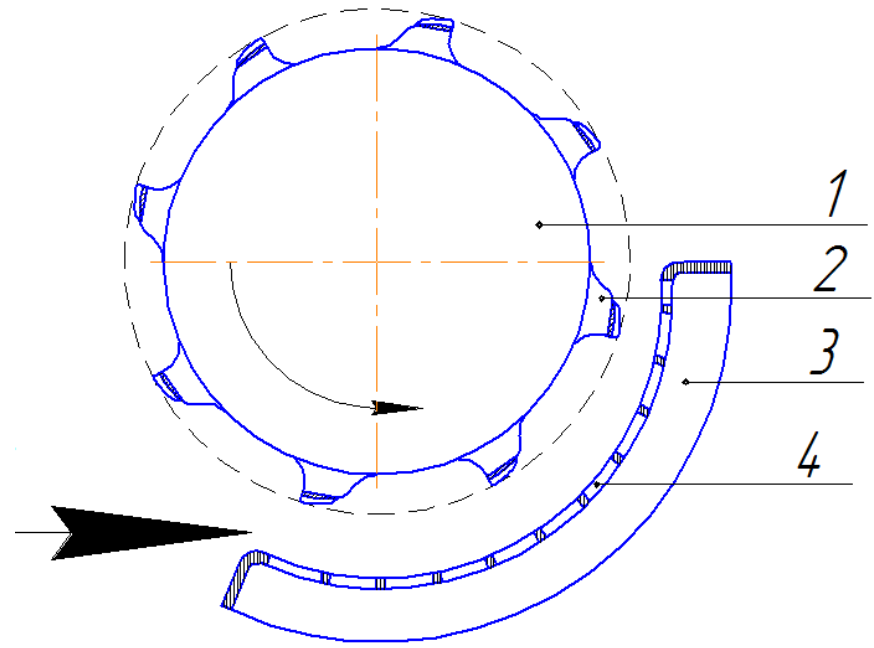

пристрій таким чином, соломистозернова маса надходить в зазор між обертовим молотильним барабаном 1 і підбарабанням 3. за рахунок удару бичів 2 по масі відбувається обмолот, в результаті чого утворюється ворох, що складається із зерна i незернової частини (соломи, полови, полови). Велика частина вільного зерна (70$80 \%$ ) сепарується через отвори 4 підбарабання 3. Інша частина зерна виділяється 3 вороху і надходить на соломовідокремлювач.

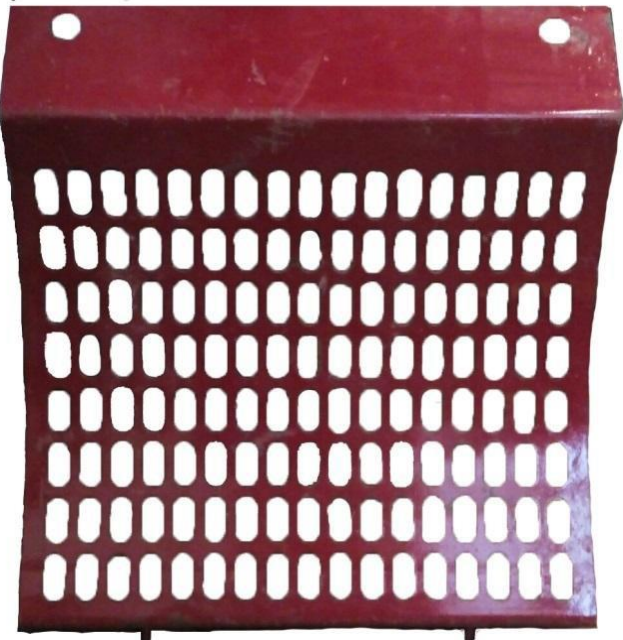

Рис. 1. Схема класичного молотильно-сепарувального пристрою зернозбирального комбайна і загальний вид секції гладкого підбарабання

Інтенсифікувати сепарації, пропонується через підбарабання шляхом демпфування підвіски підбарабання, що відрізняється тим, що сепарувальне підбарабання встановлено 3 можливістю здійснення коливання за рахунок того, що тяги підвіски 3’єднані 3 цапфами сепарувального підбарабання через пружні елементи. Недоліком цього рішення є зниження сепаруючої здатності зерна через підбарабання за збільшення товщини шару обмолочуваної соломисто- зернової маси у просторі між молотильним барабаном підбарабанням, що є причиною перевантаження соломовідокремлювача і в підсумку призводить до збільшення втрат вільним зерном за комбайном [14].

$$
\text { Збільшення зазорів }
$$

молотильно-сепарувальному пристрої між молотильним барабаном і підбарабанням веде до збільшення в ньому товщини шару обмолочуваної соломисто-зернової маси [11]. Наприклад, під час збирання 
Роговський І. Л.

зернозбиральних комбайном КЗС-9М «Славутич» зазор на виході молотильно-сепарувального

пристрою рекомендовано під час збиранні зернових колосових культур $3 . . .4$ мм. Відомо пристрій для здійснення обмолоту зернових культур, що містить молотильний барабан і підбарабання, забезпечені жорстко встановленим під підбарабанням віброзбудником, а барабан двома синхронізованими віброзбудниками, кожен віброзбудник виконаний у вигляді дебалансного вала. Недоліком цього молотильно-сепарувального пристрою є складність конструкції, підвищення енергетичних витрат на його привід, недостатня надійність пристрою, підвищені вібраційні навантаження, збільшена металоємність і значні трудовитрати на обслуговування.

На рис. 2 показана демпфуюча підвіска підбарабання. Пропонована конструкція (рис. 2) складається 3 молотильного барабана 1 з бичами 2 i підбарабання 3 має отвори 4 для сепарації дрібного оберемка з зерном. Тяги 5 підвіски, через пружний елемент $6 \quad$ з'єднані 3 цапфами 7 підбарабання. Стінка корпусу молотарки 8 знаходиться між тягами підвіски 5 і підбарабанням 3, в отворах якої проходять цапфи 7.

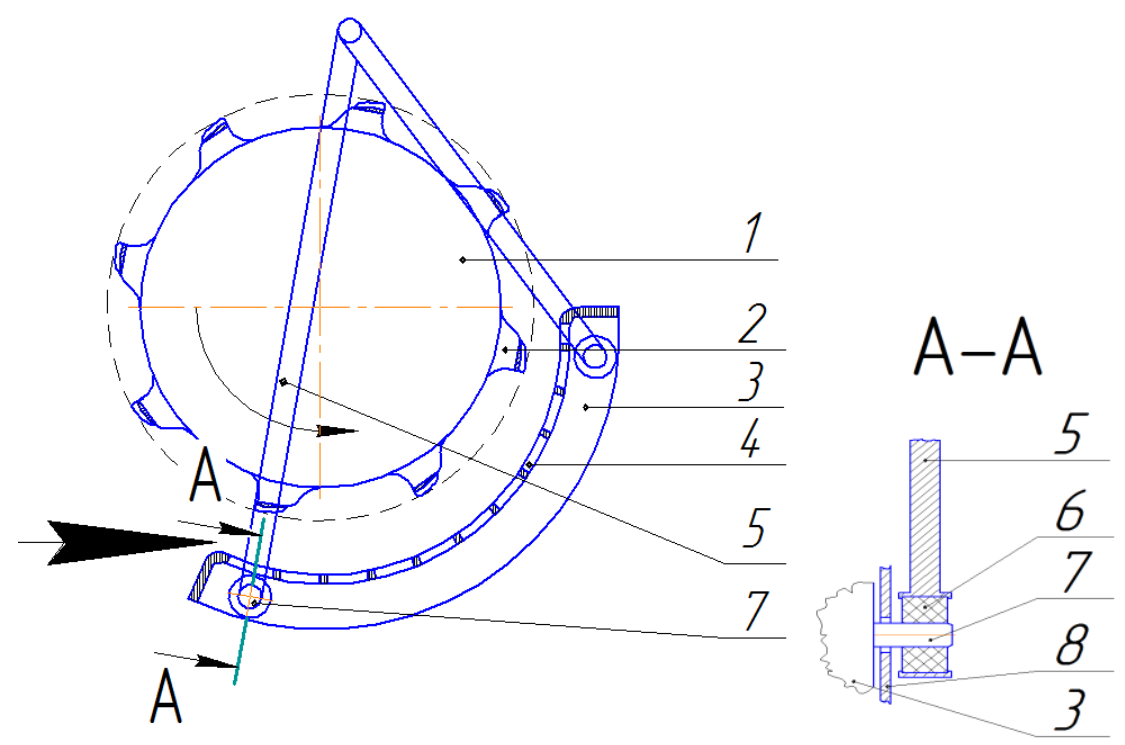

Рис. 2. Схема демпфуючої підвіски підбарабання класичного молотильно-сепарувального пристрою зернозбирального комбайна

Працює пристрій (рис. 2) так, соломисто-зернова маса надходить у зазор між обертовим молотильним барабаном 1 і підбарабанням 3. За рахунок удару бичів 2 по масі відбувається обмолот, у результаті чого утворюється ворох, що складається 3 зерна й незернової частини (соломи, полови, полови). Велика частина вільного зерна 70$80 \%$ сепарується через отвори 4 підбарабання 3. Зусилля, що виникає під час кожного удару бича, через рослинну масу передається на підбарабання з жорстко закріпленими в ньому цапфами 7, з'єднаними через 
Роговський І. Л.

пружні елементи 6 тягами 5 підвіски підбарабання. Тому що тяги 5 підвіски жорстко закріплені на корпусі молотарки комбайна, то відбувається деформація пружних елементів 6. Пульсуючі силовий вплив із боку бичів 2 молотильного барабана 1 i пружні властивості елементів 6 викликають коливальний переміщення підбарабання 33 цапфами 7 в отворах стінок молотарки 8. У результаті таких коливань підбарабання інтенсифікує процес сепарації зерна через нього. Знижується пошкодження зерна за приводу не жорсткого удару по обмолочуваній масі й більш інтенсивного виходу із зони дії бичів за рахунок поліпшення сепарації зерна. Вібрація підбарабання так само сприяє його самоочищення поверхні підбарабання.

Розглядаємо роботу молотильносепаруючого пристрою. Основне завдання молотильно-сепаруючого пристрою це вимолот зерна 3 колосу i сепарація його 3 рухомого потоку рослинної маси. Вимолот зерна являє собою руйнування зв'язку зерна 3 колосом. В сучасних молотильносепарувальних пристроях, відбувається за рахунок ударів бичів по грубому воросі й протягування його за допомогою обертового молотильного барабана в молотильного зазорі. Процес роботи молотильно-сепарувального пристрою передбачає такі етапи: надходить рослинна маса, відбувається обмолот, отримуємо грубий ворох, потім сепаруємо 3 грубого оберемка зерно. Звідси виділяємо два важливі завдання:

1) вимолот $є$ пріоритетним для зернових культур, які нерівномірно дозрівають. Для зернового збіжжя обмолот має бути м'який, так як зерно велике і руйнуються легко. Значить, вимолот не $\epsilon$ лімітуючим чинником $\mathrm{i}$ практично забезпечується за досить м'яких режимів роботи;

2) сепарація зерна 3 грубого оберемка через підбарабання, тобто отримання дрібного вороху, визначає якість роботи молотильносепарувального пристрою, так як перший чинник не $є$ лімітуючим для зернового збіжжя. Сепарація зерна ускладнена тим, що необхідно мати збільшений зазор між молотильним барабаном i підбарабанням. Значить товщина шару обмолочуваної маси збільшується, а сепарація зерна при цьому погіршується. Крім того, для товстого шару маси погіршується процес самоочищення підбарабання, за рахунок розшарування маси, так як ii нижні шари гальмуються поперечними планками.

Тому можемо відзначити, що конструкція кріплення підбарабання молотильно-сепарувального

пристрою

зернозбирального комбайна забезпечує високу ефективність сепарації зерна, дозволяє скоротити втрати вільним зерном за комбайном і зменшити його 
Роговський І. Л.

пошкодження під час збирання зернових культур.

Мета. Метою даної наукової статті $€$ висвітлення інженерного менеджменту про найчастіші характерні втрати зернового збіжжя класичним молотильносепарувальним пристроєм зернозбирального комбайна, а також про можливі причини перебігу та розвитку типових конструкцій.

Методи. На рис. 3 зображена загальна схема дослідження даної роботи. Першим етапом представленої схеми, є аналіз літературних джерел. Аналіз літературних джерел $\epsilon$ першочерговим i основним етапом роботи, який полягає в зборі та аналізі літературних джерел авторів, які працювали в досліджуваній області. Далі по схемі випливають висновки 3 аналізу літературних джерел і потім постановка завдань дослідження, по досягненню яких, досягаємо поставленої мети. Потім слід трьох теоретичних етапів: вдосконалення конструкторських параметрів молотильно-сепарувального

пристрою, аналіз травмованості зерна, вдосконалення технологічних параметрів молотильносепарувального пристрою, які в свою чергу мають свої етапи.

Опис почнемо 3 етапу вдосконалення конструкторських параметрів молотильносепарувального пристрою. На цьому етапі описується досягнення агровимог за втратами зернового збіжжя під час збирання. Досягається це оглядом патентів на винахід (корисну модель) молотильносепарувальних пристроїв, під час збиранні зернових культур. По завершенню огляду, приступаємо до обгрунтування конструкції підбарабання, отримуємо патент на корисну модель. Потім приступаємо до обгрунтування конструкції підвісу, на яку теж $є$ патент на корисну модель. Наступний етап «Аналіз травмованості зерна». У цьому етапі описується досліджувана культура, іiі фізичні й технологічні властивості. Наводиться обгрунтування методики оцінення травмування зерна, i аналіз оцінки схожості зерна, після імітації удару бичем молотильного барана, на різних частотах обертання.

Далі етап удосконалення технологічних параметрів молотильно-сепарувального

пристрою. На цьому етапі наводиться теоретичний огляд на регулювання молотильно-сепаруючого пристрою під час збирання зернових культур. Потім приводимо моделювання процесу обмолоту i сепарації молотильно-сепарувальним

пристроєм, описуємо метод визначення коефіцієнта ефективності сепарації. Далі на підставі практичних досліджень наводимо обгрунтування молотильного зазору в молотильному просторі йі швидкість обертання молотильного барабана. 
Роговський І. Л.

Передостаннім етапом у схемі «Висновки і рекомендації». На цьому дослідження йде економічне обгрунтування дослідження, в якому наводяться розрахунки економічної ефективності від впровадження підбарабання. Останній етап етапі наводяться висновки за наведеними досліджень i рекомендації по налаштуванню зернозбирального комбайна на збирання зернового збіжжя.

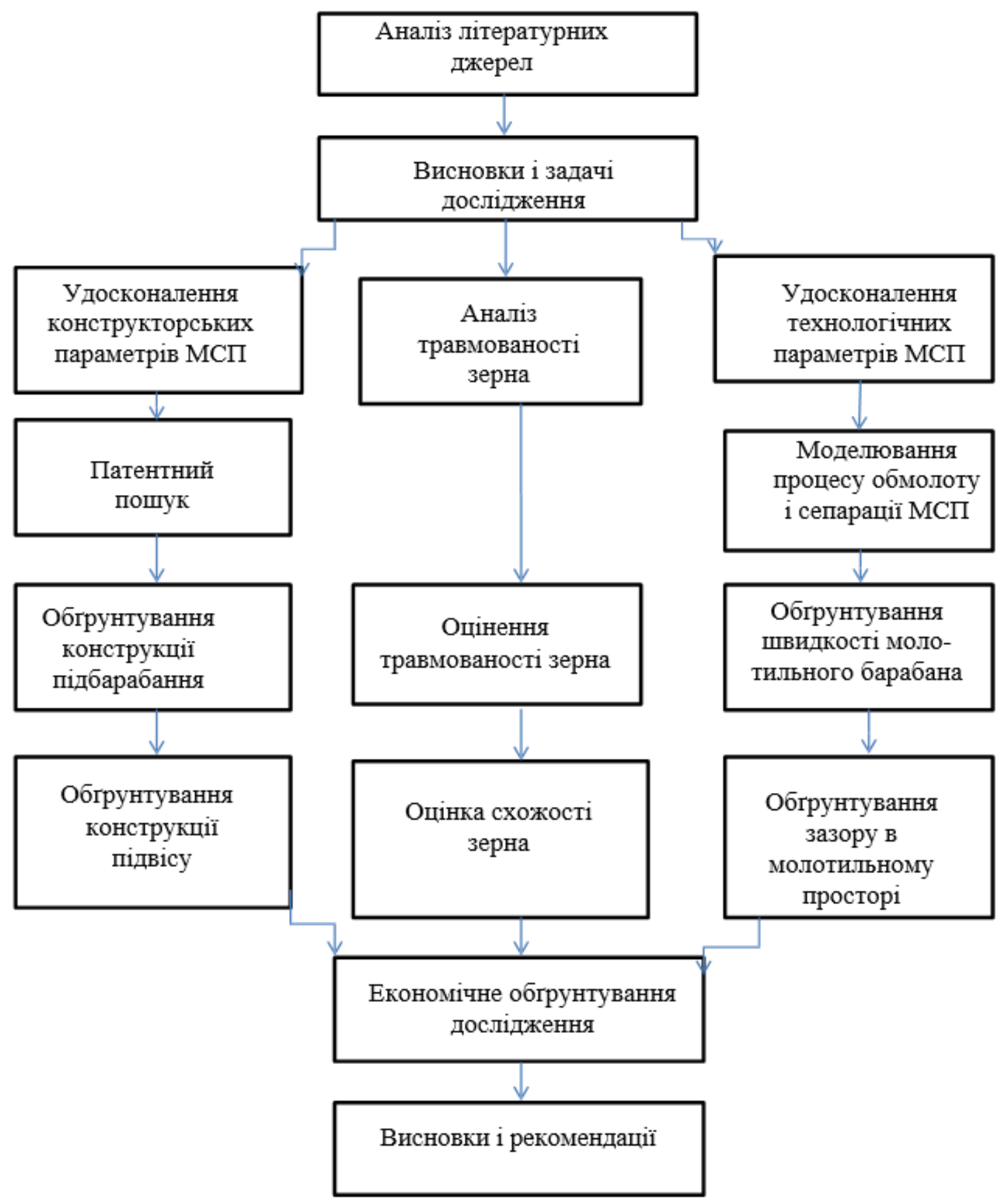

Рис. 3. Загальна схема дослідження.

Якість роботи молотильно- за коефіцієнтами недомолоту, сепарувального пристрою визначаємо сепарації, дроблення і засміченості 
Роговський І. Л.

зерна, яке надійшло на очистку. Розглянемо більш докладно коефіцієнт сепарації, так як він $\epsilon$ найвагомішим під час збирання зернового збіжжя. Коефіцієнт сепарації $\mathrm{S}_{\mathrm{M}}$ являє собою масову частку зерна, виділеного 3 обмолоченого грубого вороху в межах молотильно-сепарувального пристрою в загальній масі зерна. Сукупність полови і зерна називають дрібним зерновим ворохом; сукупність зерна, соломи і полови грубим. Разом 3 вимолотом молотильно-сепарувальний пристрій сепарує більшу частину $\left(\mathrm{S}_{\mathrm{M}}=\right.$ 0,8...0,95) зерна з вороху. У процесі використання зернозбиральних комбайнів, необхідно підвищувати коефіцієнт $\mathrm{S}_{\mathrm{M}}$ вибором регульованих параметрів i режиму роботи молотильно-сепарувального

пристрою. Сепарацію зерна в межах молотильного простору для молотильно-сепарувального пристрою різних модифікацій і типів визначали за залежністю:

$$
S_{M}=100 \times E_{M}, \%
$$

де $E_{M}-$ сходження зерна 3 молотильно-сепарувального присторою 3 соломою на початок сепаратора грубого вороху.

Сходження зерна 3 молотильносепарувального присторою з соломою на початок сепаратора грубого вороху можна визначали за залежністю:

$$
E_{M}=100 \times e^{-\mu_{M} \cdot l_{M}}, \%
$$

де $\mu_{M}-$ коефіцієнт сепарації зерна 3 молотильно-сепарувального пристрою 3 соломою на початок сепаратора грубого вороху, 1/м;

e - постійна основи натурального логарифма 2,71;

$l_{M}-$ довжина деки (молотильної частини кожуха ротора) молотильносепарувального присторою, м.

Коефіцієнт сепарації $\mu_{M \mathrm{i}}$ залежить від великої кількості чинників, серед яких одним 3 головних $\epsilon$ величина приведеної подачі маси. У функції подачі залежність має вигляд:

$$
\mu_{M \mathrm{i}}=\mu_{M 0} \times \frac{|q|}{q_{i}}
$$

де $|q|$ - пропускна здатність молотильно-сепарувального пристрою або молотарки в цілому, кг/с;

$q_{i} \quad-$ фактична величина приведеної подачі в комбайн (молотарку);

$\mu_{\text {м0 }}-$ номінальне значення коефіцієнта сепарації, яке відповідає завантаженню, рівній пропускній здатності $|q|$.

Значення показників для розрахунку втрат зерна недомолоту i сепарації зерна для різних модифікацій i типів молотильносепарувального присторою сепарація, \%:

$$
S=100 \times\left(1-e^{-\mu_{M \mathrm{i}} \cdot l_{M}}\right), \% .
$$

3 літературних джерел відомо, що інтенсивність сепарації зерна змінюється по куту обхвату молотильного барабана, тому кількість відсепарованого зерна змінюється по залежності, 
Роговський І. Л.

представленої на рис. 4: $\mathrm{F}(\varphi)$ - це функція сепарації залежно від кута обхвату підбарабання (деки), $\varphi-$ кут
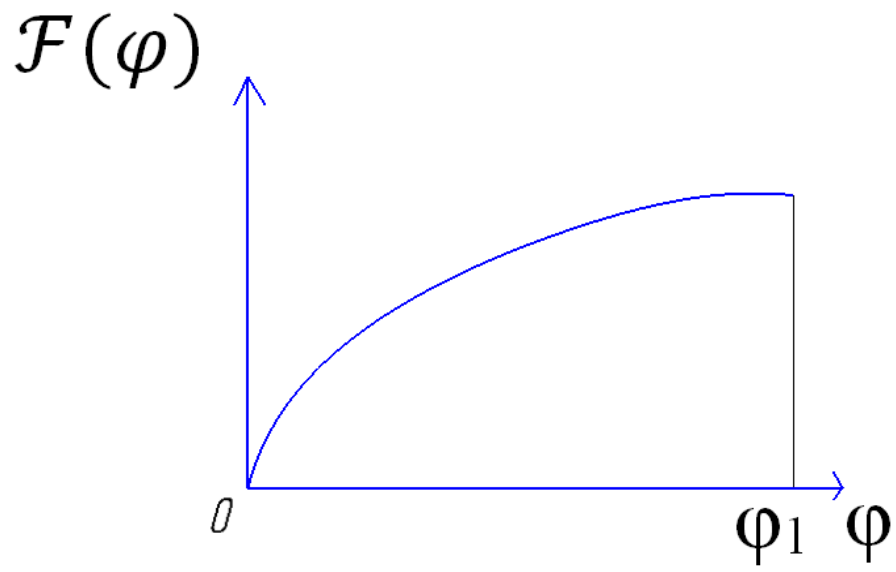

\section{Рис. 4. Залежність сепарації зерна}

Дана залежність може бути апроксимована рівнянням такого вигляду:

$$
f(\varphi)=\frac{d m_{c}}{d \varphi}=a \varphi^{2}+b \varphi+c .
$$

Скористаємося початковими умовами, підставляємо $\varphi=0$ (рослинна маса знаходиться на вході в молотильний зазор):

$$
f(0)=a 0^{2}+b 0+c, c=0 .
$$

Швидкість зміни процесу показує похідна $f(\varphi)$, продиференціюємо рівняння $f(\varphi)=$ $\frac{d m_{c}}{d \varphi}=a \varphi^{2}+b \varphi+c$, тоді маємо:

$$
f^{\prime}(\varphi)=2 a \varphi+b .
$$

Для визначення постійних коефіцієнтів скористаємося початковими умовами, підставляємо $\varphi=0$ (рослинна маса знаходиться на вході в молотильний зазор):

$$
f^{\prime}(0)=2 a 0+b, b=k .
$$

Параметр $b$ характеризує процес сепарації, позначимо його через k. Для визначення значення коефіцієнтів, скористаємося початковими умовами $\varphi=\varphi_{1}$. обхвату деки, $\varphi_{1}-$ максимальний кут обхвату деки. 
Роговський І. Л.

Проаналізуємо вплив кожного

отримання

макропошкодження

чинника на пошкоджуваність зерна.

На рис. 5 представлена

(дроблення,

розчавлювання, залежність впливу вологості на макро обрушення, відколи), а зменшення вологості

збільшує i мікропошкодження зерна. За збільшення вологості зерна збільшуються i мікропошкодження, так як оболонка зерна i насіння за підвищення вологості стають м'якшими і відповідно більш сприйнятливими до пошкоджень, що тягне за собою збільшення мікропошкодження (подряпини, тріщини, вибоїни, пошкодження оболонки). А зменшення вологості, призводить до зменшення мікропошкодження, $\quad$ у зв'язку зі зміцненням (отвердінням) оболонки зерна. Зворотна залежність у макропошкодження. Зі збільшенням вологості, зерно стає м'яким i макропошкодження, так як зерно стає більш твердим і під час взаємодії 3 металевими поверхнями відбувається жорсткий удар. Залежність макро- i мікропошкодження відрізняється у процентному співвідношенні, тому що ймовірність отримання мікропошкодження набагато вище, ніж макро, це пояснюється тим, що зерно спочатку отримує мікропошкодження, а потім за отримання додаткового впливу переходить у розряд макропошкодження. Так само для отримання мікропошкодження, силовий вплив, необхідно набагато менший, ніж під час отримання пружним, що різко зменшує шанси на макропошкодження.

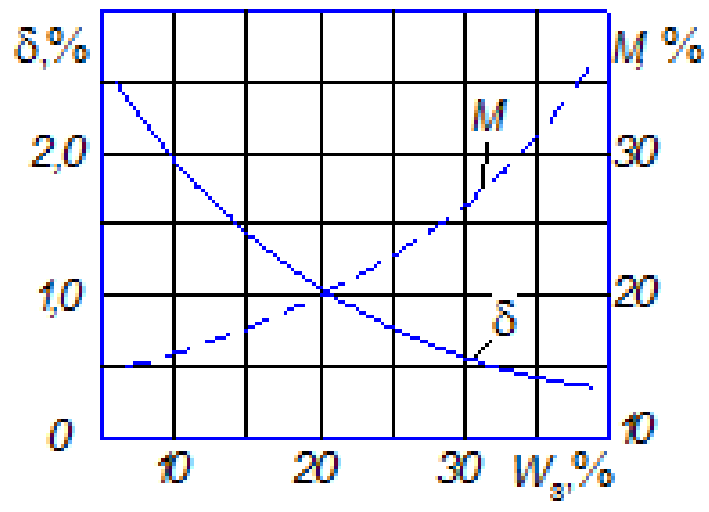

Рис. 5. Вплив вологості на макропошкодження і мікропошкодження зерна: $\delta$ - дроблення, М - мікропошкодження

На рис. 6 представлена залежність колової швидкості бичів на макропошкодження i мікропошкодження зерна. $3 \mathrm{a}$ збільшення колової швидкості бичів, у зерна збільшуються мікропошкодження, так як оболонка зерна i насіння при підвищенні окружної швидкості бичів стають більш сприйнятливими. Так як збільшується сила, 3 якою бич впливає на зерно, то це тягне за собою збільшення мікропошкодження (подряпини, тріщини, вибоїни, 
Роговський І. Л.

пошкодження оболонки). Зменшення колової швидкості бичів, призводить до зменшення мікропошкодження, у зв'язку зі зменшенням сили впливу бича на зерно. Аналогічна залежність у макропошкодження. Зі збільшенням колової швидкості бичів, зерно отримує більш інтенсивний вплив, що збільшує шанси на отримання макропошкодження (дроблення, розчавлювання, обрушення, відколи). I навпаки, зменшення колової швидкості бичів зменшує макропошкодження

мікропошкодження відрізняється $\mathrm{y}$ процентному співвідношенні, так як шанси отримання мікропошкодження набагато вище, ніж макро, це пояснюється тим, що зерно спочатку отримує мікропошкодження, а потім за отримання додаткового впливу переходить у розряд макропошкодження. Плюс для отримання мікропошкодження, сили удару, необхідно набагато менше, ніж за отримання макропошкодження. макропошкодження. Залежність

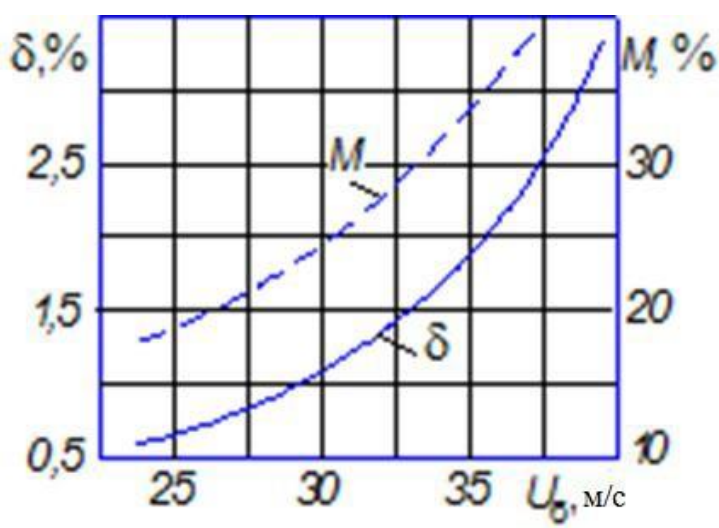

Рис. 6. Вплив колової швидкості бичів на макропошкодження i мікропошкодження зерна

На рис. 7 представлена залежність зазору в молотильного просторі на макропошкодження i мікропошкодження зерна. За збільшення зазору в молотильного просторі, у зерна зменшуються мікропошкодження, так як збільшується товщина рослинної маси в молотильного просторі в результаті зменшується ефект удару бича по рослинній масі й зменшується ефект перетирання, так як збільшує i сила, з якою бич вдаряє по зерну, що тягне за собою збільшення мікропошкодження (подряпини, тріщини, вибоїни, пошкодження оболонки). А зменшення зазору в молотильного просторі, призводить до збільшення мікропошкодження, у зв'язку зі зменшенням сили впливу бича на рослинну масу. Аналогічна залежність у макропошкодження. Зі збільшенням зазору в молотильного просторі, зерно отримує меншої шкоди, що зменшує шанси на отримання макропошкодження (дроблення, розчавлювання, обрушення, відколи), i навпаки зменшення зазору в молотильного просторі збільшує 
Роговський І. Л.

макропошкодження. макропошкодження мікропошкодження відрізняється у процентному співвідношенні, так як шанси отримання мікропошкодження

Залежність о мікропошкодження, сили удару, необхідно набагато менше, ніж при отриманні макропошкодження.

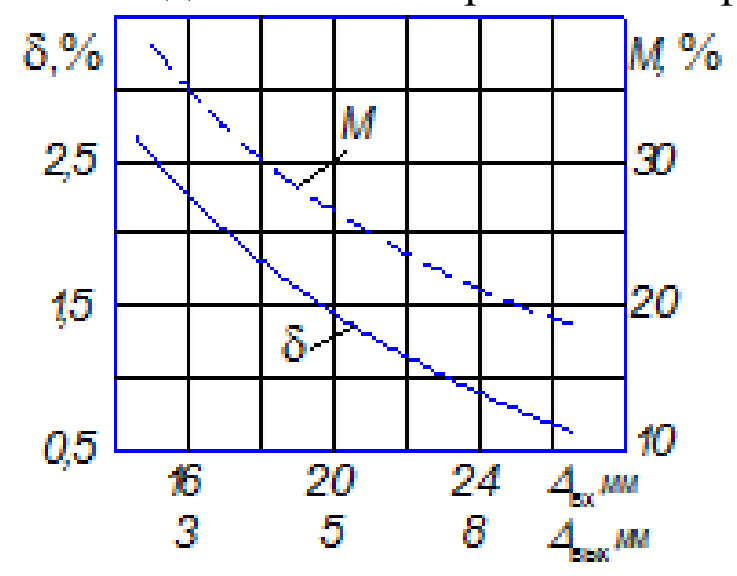

Рис. 7. Вплив зазору в молотильного просторі на макропошкодження i мікропошкодження зерна

На рис. 8 представлена залежність величини подачі маси у молотарку на макропошкодження i мікропошкодження зерна. За збільшення величини подачі маси у молотарку, у зерна зменшуються мікропошкодження, так як збільшується швидкість проходження і щільність рослинної маси у молотильного просторі. У результаті зменшується ефект удару бича по рослинній масі й зменшується ефект перетирання, так як зменшується сила, 3 якою бич впливає на зерно, що тягне за собою зменшення мікропошкодження (подряпини, тріщини, вибоїни, пошкодження оболонки). А зменшення величини подачі маси в молотарку, призводить до збільшення мікропошкодження, у зв'язку зі збільшенням сили впливу бича на рослинну масу. Аналогічна залежність у макропошкодження. Зі збільшенням величини подачі маси в молотарку, зерно отримує менший вплив, що зменшує шанси на отримання макропошкодження (дроблення, розчавлювання, обрушення, відколи), i навпаки зменшення величини подачі маси в молотарку збільшує макропошкодження. Залежність макропошкодження мікропошкодження відрізняється у процентному співвідношенні, так як шанси отримання мікропошкодження набагато вище, ніж макро, це пояснюється тим, що зерно спочатку отримує мікропошкодження, а потім при отриманні додаткового впливу переходить у розряд макропошкодження. Така ж можливість для отримання мікропошкодження, сили удару, 
Роговський І. Л.

необхідно набагато менше, ніж при

отриманні макропошкодження.

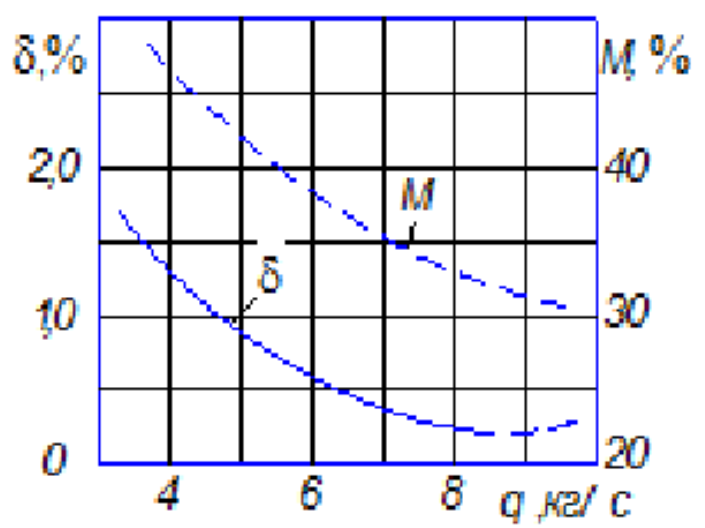

Рис. 8. Вплив величини подачі маси в молотарку на макропошкодження і мікропошкодження зерна

За збільшенні частоти обертання нагріву при сушінні на (коловї швидкості) шнека, у зерна збільшуються макропошкодження (дроблення, розчавлювання, обрушення, відколи), так як збільшується швидкість обертання шнека, відповідно збільшується сила, з якою шнек впливає на зерно, так як збільшується вплив, з якої бич вдаряє по зерну, що тягне за собою збільшення мікропошкодження (подряпини, тріщини, вибоїни, пошкодження оболонки).

На рис. 9 представлена залежність впливу температури вологи.

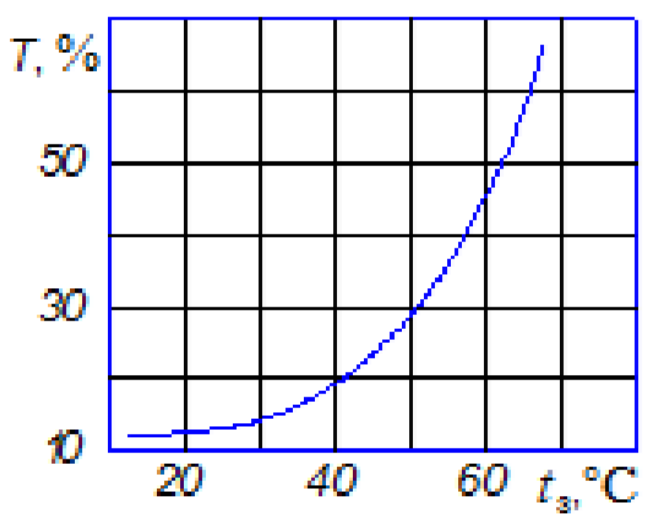

Рис. 9. Вплив температури нагріву при сушінні $t_{3}$ на тріщинуватість зерна $T$ 
Роговський І. Л.

Пошкодження зерна під час обмолоту в молотарці відбувається в основному завдяки впливу окружний лінійної швидкості молотильного барабана i зазору між молотильним барабаном i підбарабанням (декою). Тому зазор у молотильного просторі $є$ змінним і змінюється у бік зменшення від входу рослинної маси в молотильний пристрій до його виходу. Узагальнюючим параметром, ми використовував зазор у молотильного просторі на виході 3 молотарки. У зв'язку 3 цим, початок випробувань був за частоти обертання барабана $450 \mathrm{xв}^{-1}$. Під час випробування було встановлено, що найбільший вплив на пошкодження зерна надає колова лінійна швидкість молотильного барабана. Так, за збільшення частоти обертання барабана на 100 хв$^{-1} 3450$ до $550 \quad \mathrm{xB}^{-1}, \quad$ пошкодження збільшувалися 3 1,5 \% до 5,5\%, тобто практично в 4 рази. Залежність пошкоджень зерна від оборотів молотильного барабана показана на рис. 10 .

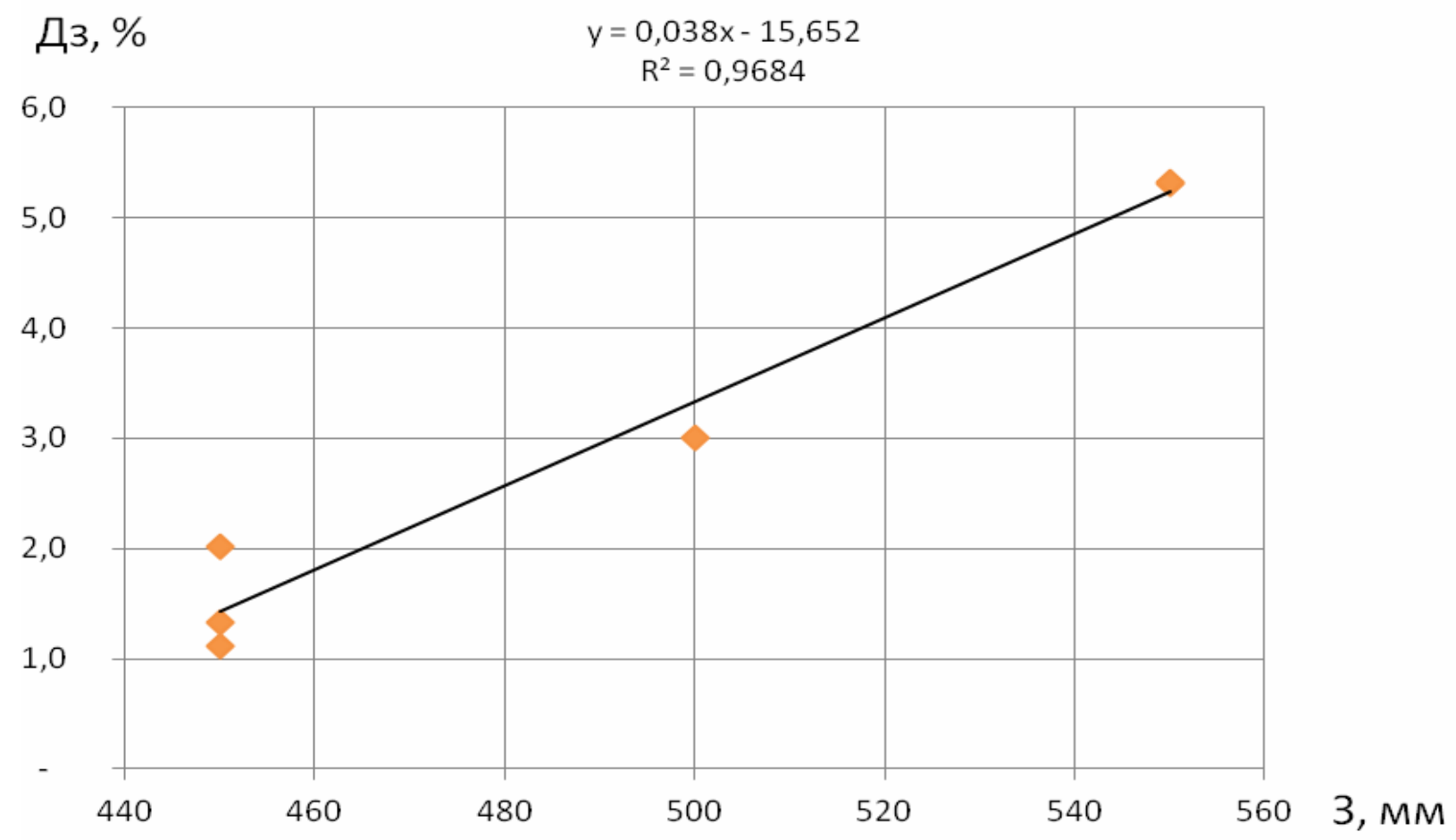

Рис. 10. Залежність пошкоджень зерна від швидкості обертання молотильного барабана $\left(\mathrm{xB}^{-1}\right)$ за зазору на виході молотарки 10 мм

На підставі даних мінімальні оберти барабана представлених на рис. 10 можна збільшують величину крутного стверджувати, що частота обертання моменту на його привід. Це молотильного барабана не повинна призводить до збільшення бути збільшена більш за $450 \mathrm{xB}^{-1}$. Це навантаження на пас приводу мінімально можливе значення цієї варіатора молотарки, що може величину на комбайні КЗС-9М. викликати його проковзування. Цей Водночас необхідно зазначити, що факт збільшує ймовірність забивання 
Роговський І. Л.

молотарки, що призводить до порушення технологічного процесу комбайна i велику трудомісткість усунення відмов. У цьому випадка підвищуються вимоги до рівномірності завантаження молотарки комбайна і не допущення іiі перевантаження, навіть короткочасної.

Д3, \%

Зменшення зазору на виході молотарки 310 до 3 мм величина макропошкодження зерна (дроблення) відповідно збільшувалася від 1,6 до 3,0\%. Це значно менше, ніж за зміни числа обертів молотильного барабана. Залежність пошкодження зерна від зазору на виході молотарки показана на рис. 11.

$y=0,0083 x^{2}-0,3303 x+4,0637$

$R^{2}=0,8592$

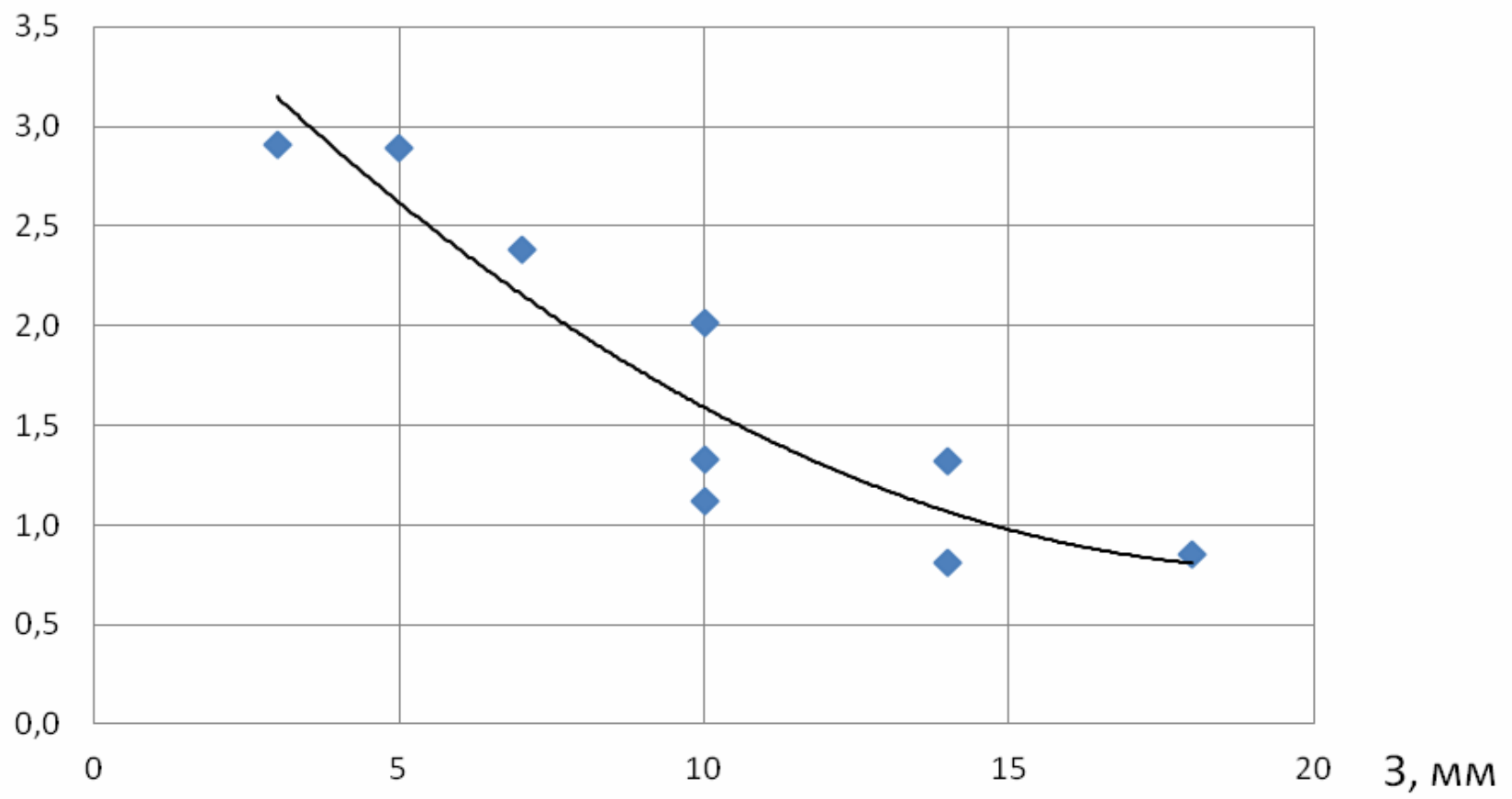

Рис. 11. Залежність пошкоджень зерна від зазору на виході молотарки за частоти обертання молотильного барабана $450 \mathrm{xB}^{-1}$

Важливим чинником $є$ те, що крім макропошкодження $\epsilon$ мікропошкодження зерна, a їx величина значно більша. Залежність мікропошкодження зерна від зазору на виході молотарки показана на рис. 12. Аналізуючи цю залежність видно, що зменшення зазору на виході молотарки 318 до 3 мм мікропошкодження відповідно збільшуються з 3 до $13 \%$. Цей факт найбільш значущий, ніж макропошкодження, так як мікропошкодження у кілька разів вище. 
Роговський І. Л.

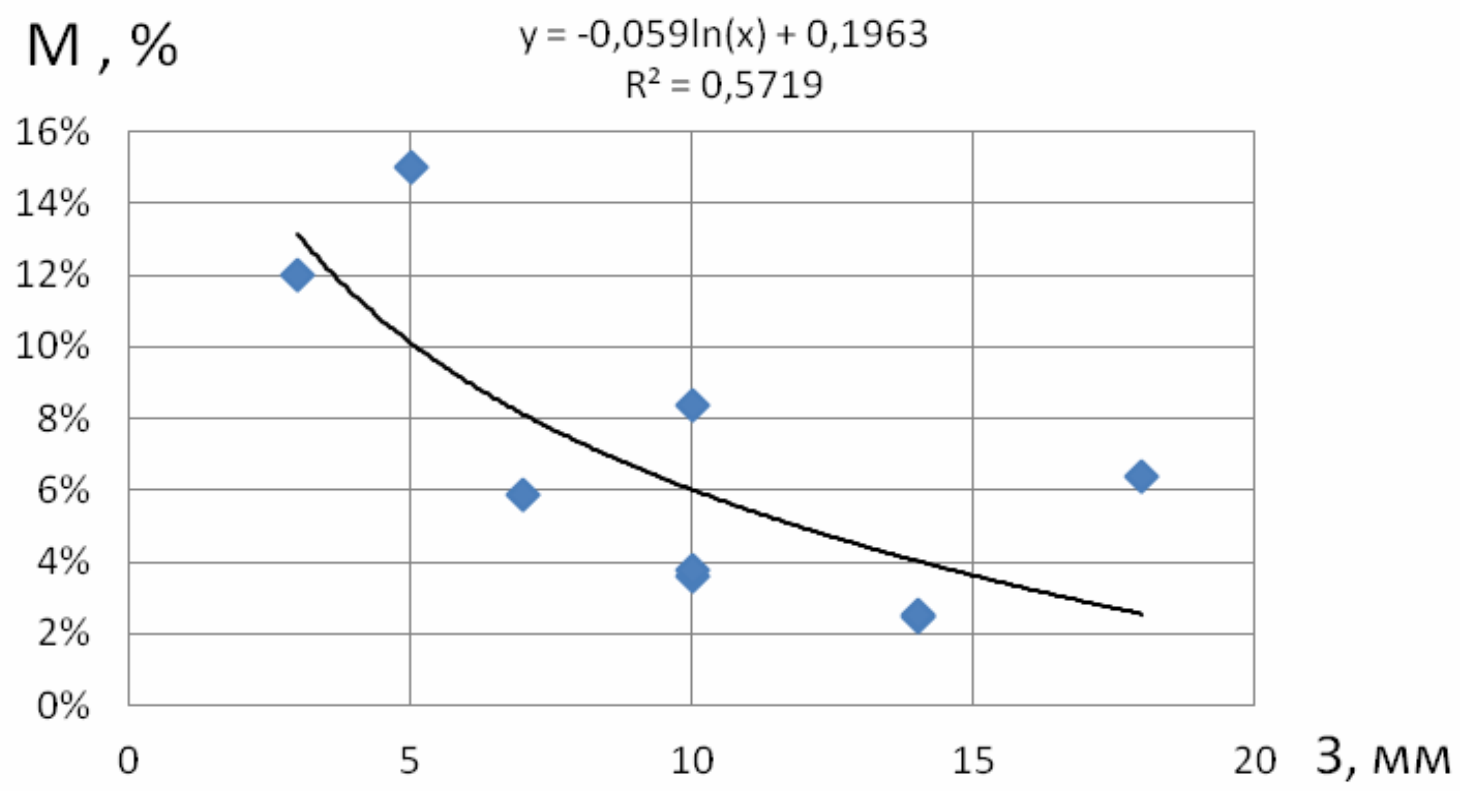

Рис. 12. Залежність мікропошкодження зерна від зазору на виході молотарки за частоти обертання молотильного барабана $450 \mathrm{xB}^{-1}$

На жаль, нормативними недомолоту немає. Тому виникає документами, не встановлено допустиму величину дроблення зерна робочими органами машин під час збирання, деякі науковці орієнтуються на $3 \%$. питання, чи можливо подальше збільшення зазору на виході молотарки, щоб отримати подальше зниження мікропошкодження зерна.

Як зазначалося вище зернові культури добре вимолочується і втрат Розглянемо залежність втрат вільним зерном за комбайном у залежності від зазору на виході молотарки (рис. 13).

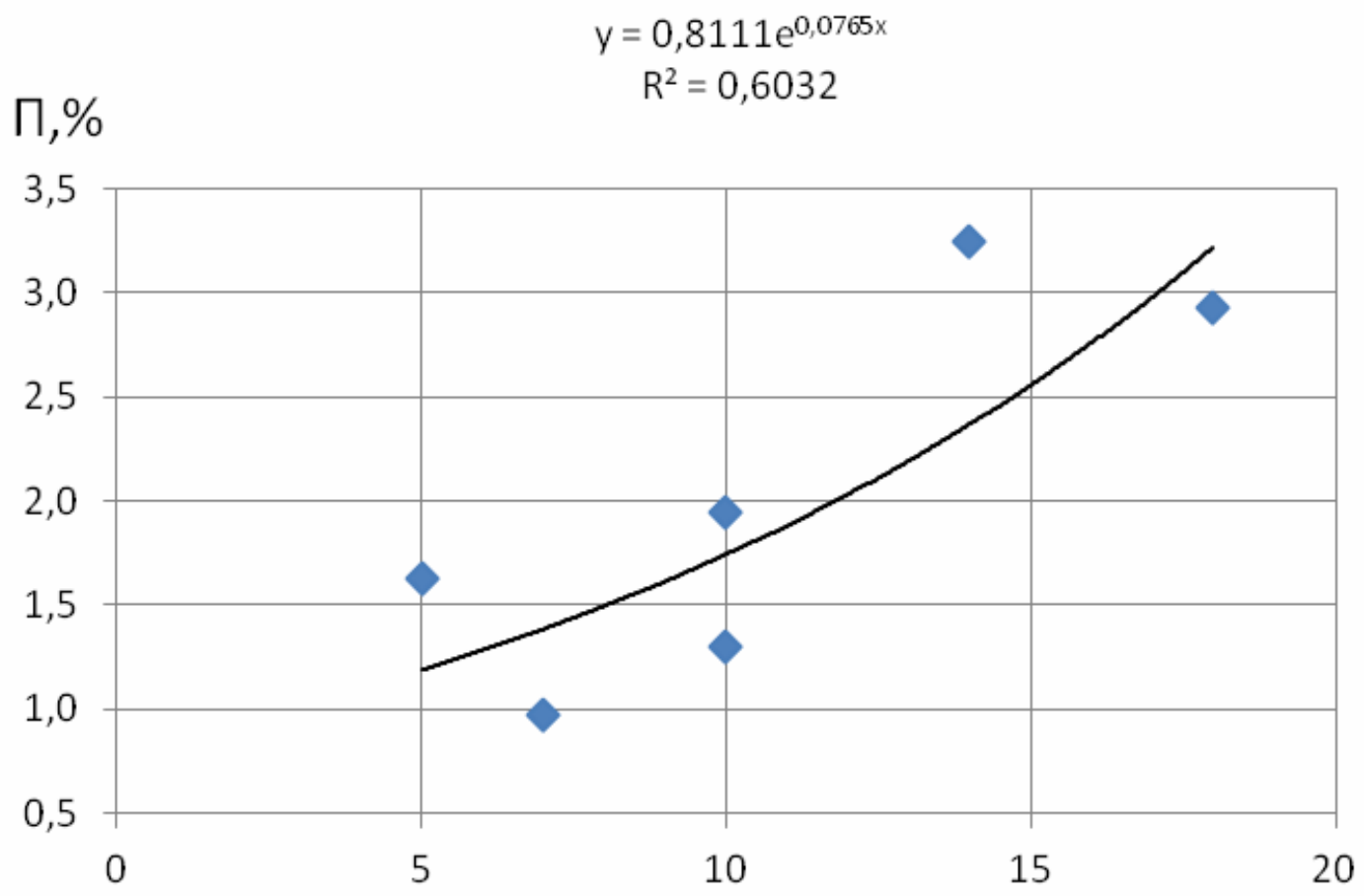

Рис. 13. Залежність втрат вільним зерном від зазору на виході молотарки за частоти обертання молотильного барабана 450 хв$^{-1}$ 
Роговський І. Л.

Аналізуючи представлену на рис. 13 залежність, необхідно враховувати той факт, що зі збільшенням зазору на виході молотарки знижується інтенсивність сепарації зерна в молотильної частини через підбарабання. Це пов'язано зі збільшенням товщини шару обмолочуваної зернової маси. Зерну значно важче в цьому випадку виділятися з вороху. А нам необхідно, щоб основна частина зерна до $80 \%$ сепарованого саме в молотарці. У нашому ж випадку, на рахунок погіршення процесу сепарації недостатня кількість зерна виділяється в молотарці. Отже, більше його потрапляє на соломотряс. Тоді соломотряс не справляється в повній мірі зі своєю функцією, що призводить до збільшення втрат вільним зерном за комбайном. Тому збільшувати зазор на виході молотарки недоцільно більше 12 мм.

Основними чинниками, що впливають на величину втрат зерна під час його обмолоту $\epsilon$ подача, фракційний склад i вологість обмолочуючого матеріалу, конструктивні й режимні параметри молотильно-сепаруючих пристроїв зернозбирального комбайна. Тому втрати зерна можна знизити такими способами:

1) збільшити частоту обертання молотильного барабана, для того щоб швидше просувати рослинну масу, але за високих швидкостей зерно буде сильно дробитися;

2) зменшити зазор між бичами i підбарабанням, для того щоб зменшити ефект розшаровування рослинної маси і збільшити швидкість проходження, але за малого зазору відбувається сильне дроблення зерна;

3) зменшити подачу рослинної маси, для того щоб зменшити забивання підбарабання, але за малої подачі, економічно неефективна прибирання культури;

4) прибрати поперечні планки 3 підбарабання, тим самим усунути процес забивання, шляхом процесу самоочищення;

5) інтенсифікувати процес сепарації зерна.

За цим, можна зробити висновок, що зерно має великий розмір, легко вимолочується, тому за малого зазору, буде збільшуватися пошкодження зерна, а за великого зазору буде збільшуватися товщина рослинної маси і відповідно погіршуватися сепарація зерна за допомогою залипання молотильносепарувального пристрою, що підтверджується польовими дослідами. Залипання молотильносепарувального пристрою представлено на рис. 14. 
Роговський І. Л.

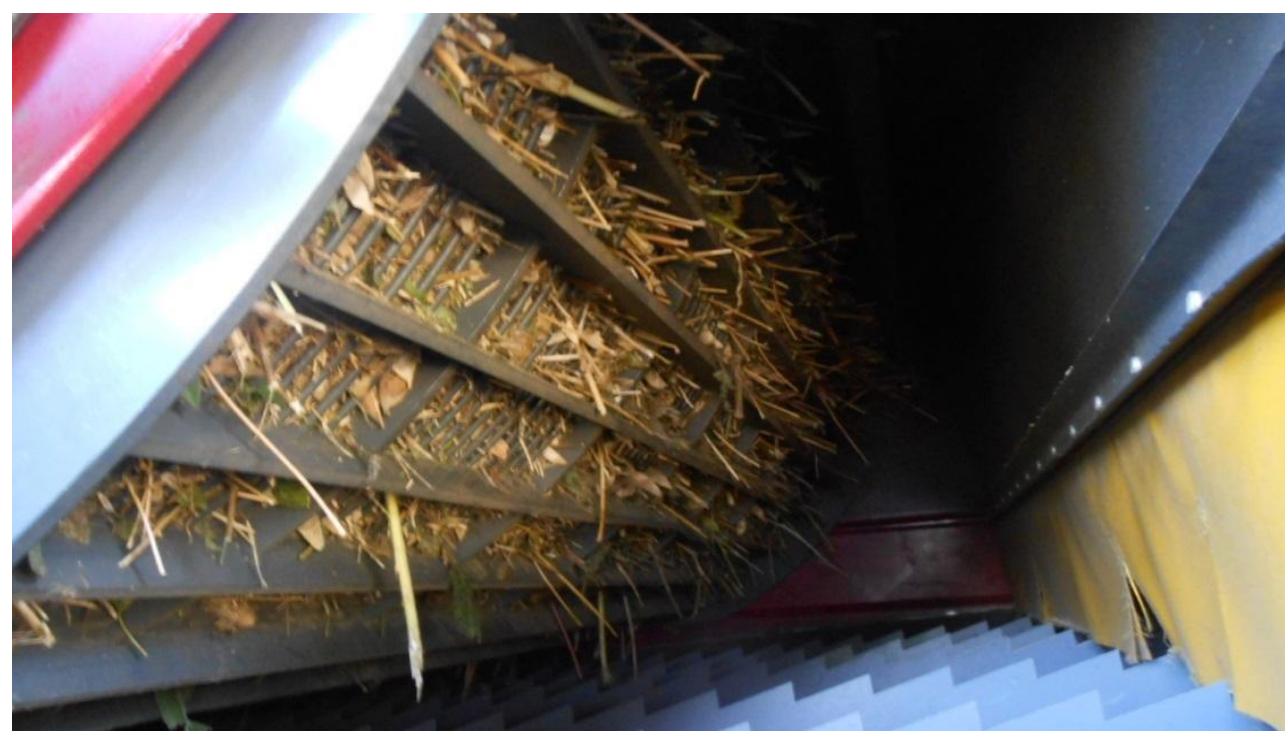

Рис. 14. Процес залипання підбарабання молотарки під час збирання зернового збіжжя

Висновки і перспективи. Отже, обгрунтовано доцільність змінити конструкцію класичного молотильносепарувального пристрою зернозбирального комбайну, спрямованої інтенсифікацію процесу сепарації усунення забивання підбарабання.

Запропоновано на збиранні зернового збіжжя сільськогосподарських

культур зернозбиральним комбайном КЗС-9М «Славутич» встановити частоту обертання молотильного барабана $450 \mathrm{xB}^{-1}$. Для забезпечення допустимої величини пошкодження зерна i зниження втрат вільним зерном зазор на виході молотарки необхідно встановити 12 мм.

5. Dubbini M., Pezzuolo A., De Giglio M., Gattelli M., Curzio L., Covi D., Yezekyan T., Marinello F. Last generation instrument for agriculture multispectral data collection. CIGR Journal. 2017. Vol. 19. P. 158-163.

6. Hrynkiv A., Rogovskii I., Aulin V., Lysenko S., Titova L., Zagurskiy O., Kolosok I. Development of a system for determining the informativeness of the diagnosing parameters of the cylinder-piston group of the diesel engines in operation. Eastern-European Journal of Enterprise Technologies. 2020. Vol. 3(105). P. 19-29.

7. Luo A. C. J., Guo Y. Vibro-impact dynamics. Monograph. Berlin: Springer-Verlag. 2018. $213 \mathrm{p}$.

8. Masek J., Novak P., Jasinskas A. Evaluation of combine harvester operation costs in different working conditions. Activites Coutaboeuf Bp 112, F-91944 Cedex A, France, Vol. 76, UNSP 04036. 
Роговський І. Л.

Engineering for Rural Development. 2017. Vol. 16. P. 1180-1185.

9. Mirzazadehl A., Abdollahpour S., Mahmoudi A., Ramazani B. Intelligent modeling of material separation in combine harvester's thresher. ANN International Journal of Agriculture and Crop Sciences. 2012. Vol. 4(23). P. 1767-1777.

10. Nazarenko I., Dedov O., Bernyk I., Rogovskii I., Bondarenko A., Zapryvoda A., Titova L. Study of stability of modes and parameters of motion of vibrating machines for technological purpose. Eastern-European Journal of Enterprise Technologies. 2020. Vol. 6 (7-108). P. 71-79. doi: 10.15587/17294061.2020.217747.

11. Pinzi S., Cubero-Atienza A. J., Dorado M. P. Vibro-acoustic analysis procedures for the evaluation of the sound insulation characteristics of agricultural machinery. Journal of Sound and Vibration. 2016. Vol. 266 (3). P. 407-441.

12. Rogovskii I. L., Titova L. L., Voinash S. A., Sokolova V. A., Tarandin G. S., Polyanskaya O.A. Modeling the weight of criteria for determining the technical level of agricultural machines. IOP Conference Series: Earth and Environmental Science. 2021. Vol. $677 . \quad$ P. $022100 . \quad$ doi:10.1088/17551315/677/2/022100.

13. Rogovskii I., Grubrin O. Accuracy of converting videoendoscopy combine harvester using generalized mathematical model. Scientific Herald of National University of Life and Environmental Science of Ukraine. Series: technique and energy of APK. Kyiv, Ukraine. 2018. Vol. 298. P. 149-156.

14. Rogovskii I. L. Probability of preventing loss of efficiency of agricultural machinery during exploitation. Scientific Herald of National University of Life and Environmental Science of Ukraine. Series: Technique and energy of APK. Kyiv. 2017. Vol. 258. P. 399-407.

15. Sergejeva N.,

Aboltins A., Strupule L., Aboltina B. Mathematical knowledge in elementary school and for future engineers. Engineering for Rural Development. 2018. Vol. 17. P. 1166-1172.

16. Sukhanova M. V., Sukhanov A. V., Voinash S. A. Intelligent control systems for dynamic mixing processes in seed processing machines with highly elastic working bodies. Engineering Technologies and Systems. 2020. Vol. 30(3). P. 340-354.

17. Xu L., Wei C., Liang Z., Chai X., Li Y. Development of rapeseed cleaning loss monitoring system and experiments in a combine harvester. Biosystems engineering. 2019. Vol. 178. P. 118-130.

18. Yata V. K., Tiwari B. C., Ahmad I. Nanoscience in food and agriculture: research, industries and patents. Environmental Chemistry Letters. 2018. Vol. 16. P. 79-84.

19. Zagurskiy O., Ohiienko M., Rogach S., Pokusa T., Titova L., Rogovskii I. Global supply chain in context of new model of economic growth. Conceptual bases and trends for development of social-economic processes. Monograph. Opole. Poland. 2018. P. 64-74.

\section{References}

1. Astashev, V., Krupenin, V. (2017). Efficiency of vibration machines. Engineering for rural development, 16, 108-113.

2. Brown, R., Richards, A. (2018). Engineering principles of agricultural machinery. ASABE, 84(2), 1120-1132.

3. Dawoud, M., Taha, I., Ebeid, S. (2016). Mechanical behaviour of ABS: an experimental study using FDM and injection moulding techniques. Journal of Manufacturing Processes, 21, 39-45.

4. Drga, R., Janacova, D., Charvatova, H. (2016). Simulation of the PIR detector active function. Proceedings of 20th International conference on Circuits, Systems, Communications and Computers (CSCC 2016), July 14-17, 2016, E D P Sciences, 17 Ave Du Hoggar Parc D Activites Coutaboeuf Bp 112, F-91944 Cedex A, France, 76, 04036.

5. Dubbini, M., Pezzuolo, A., De Giglio, M., Gattelli, M., Curzio, L., Covi, D., Yezekyan, T., Marinello, F. (2017). Last generation instrument for agriculture multispectral data collection. CIGR Journal, 19, 158-163.

6. Hrynkiv, A., Rogovskii, I., Aulin, V., Lysenko, S., Titova, L., Zagurskiy, O., Kolosok, I. (2020). Development of a system for determining the informativeness of the diagnosing parameters of the cylinder-piston group of the diesel engines in operation. Eastern-European Journal of Enterprise Technologies, 3(105), 19-29. 
Роговський І. Л.

7. Luo, A. C. J., Guo, Y. (2018). Vibroimpact dynamics. Monograph. Berlin: Springer-Verlag, 213.

8. Masek, J., Novak, P., Jasinskas, A. (2017). Evaluation of combine harvester operation costs in different working conditions. Engineering for Rural Development, 16, 1180 1185.

9. Mirzazadehl, A., Abdollahpour, S., Mahmoudi, A., Ramazani, B. (2012). Intelligent modeling of material separation in combine harvester's thresher. ANN International Journal of Agriculture and Crop Sciences, 4(23), 1767-1777.

10. Nazarenko, I., Dedov, O., Bernyk, I., Rogovskii, I., Bondarenko, A., Zapryvoda, A., Titova, L. (2020). Study of stability of modes and parameters of motion of vibrating machines for technological purpose. Eastern-European Journal of Enterprise Technologies, 6(7-108), 71-79, doi: 10.15587/1729-4061.2020.217747.

11. Pinzi, S., Cubero-Atienza, A. J., Dorado, M. P. (2016). Vibro-acoustic analysis procedures for the evaluation of the sound insulation characteristics of agricultural machinery. Journal of Sound and Vibration, 266(3), 407-441.

12. Rogovskii, I. L., Titova, L. L., Voinash, S. A., Sokolova, V. A., Tarandin, G. S., Polyanskaya, O. A. (2021). Modeling the weight of criteria for determining the technical level of agricultural machines. IOP Conference Series: Earth and Environmental Science, 677, 022100. doi:10.1088/1755-1315/677/2/022100.

13. Rogovskii, I., Grubrin, O. (2018). Accuracy of converting videoendoscopy combine harvester using generalized mathematical model. Scientific Herald of National University of Life and Environmental Science of Ukraine. Series: technique and energy of APK, 298, 149-156.

14. Rogovskii, I. L. (2017). Probability of preventing loss of efficiency of agricultural machinery during exploitation. Scientific Herald of National University of Life and Environmental Science of Ukraine. Series: Technique and energy of APK, 258, 399-407.

15. Sergejeva, N.,

Aboltins, A.,

Strupule, L., Aboltina, B. (2018). Mathematical knowledge in elementary school and for future engineers. Engineering for Rural Development, 17, 1166-1172.

16. Sukhanova, M. V., Sukhanov, A. V., Voinash, S. A. (2020). Intelligent control systems for dynamic mixing processes in seed processing machines with highly elastic working bodies. Engineering Technologies and Systems, 30(3), 340-354.

17. Xu, L., Wei, C., Liang, Z., Chai, X., Li, Y. (2019). Development of rapeseed cleaning loss monitoring system and experiments in a combine harvester. Biosystems engineering, 178, 118-130.

18. Yata, V. K., Tiwari, B. C., Ahmad, I. (2018). Nanoscience in food and agriculture: research, industries and patents. Environmental Chemistry Letters, 16, 79-84.

19. Zagurskiy, O., Ohiienko, M., Rogach, S., Pokusa, T., Titova, L., Rogovskii, I. (2018). Global supply chain in context of new model of economic growth. Conceptual bases and trends for development of social-economic processes. Monograph. Opole. Poland, 64-74.

\section{АНАЛИЗ ПОТЕРЬ ЗЕРНА КЛАССИЧЕСКИМ МОЛОТИЛЬНО-СЕПАРИРУЮЧИМ УСТРОЙСТВОМ ЗЕРНОУБОРОЧНОГО КОМБАЙНА И. Л. Роговский}

Аннотация. На основании анализа современных отечественных $и$ зарубежных комбайнов установлено, что они характеризуются традиционной схемой молотильно-сепарирующего устройства, которая включает последовательное расположенные бильного молотильного аппарата $u$ клавишный соломотряс. Конструкиия подбарабаньев из прутков с поперечньли пластинами характеризуется, прежде всего, интенсификацию процесса вымолота зерна. Зерновые культуры вылолачиваются легко, поэтому нет 
Роговський І. Л.

необходимости в интенсификаџии вымолота. Например, при машиноиспользовании зерноуборочного комбайна КЗС-9М «Славутич» при зазоре на выходе молотильного барабана с подбарабаньем в 18 мм и частоте

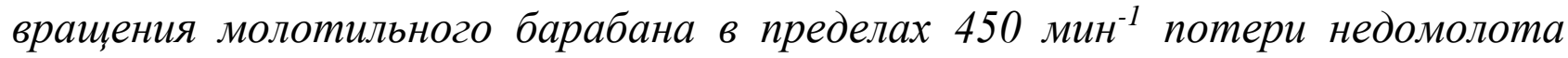
зерна отсутствовали при испьттаниях. В данном случае поперечные пластины подбарабанья являются препятствием для перемещзения обмолачиваемой массы в молотилке, при этом они образуют за планкой определенное мертвое пространство, в котором накапливается мелкодиссперсная составляющая растительной массы.

Качество эксплуатации молотилки зерноуборочного комбайна определяли по коэффициентам недомолота, сепарации, дробления и засоренности, поступившего на очистку зерна.

Определено, что потери и травмирование зерна при обмолоте в молотильно-сепарирующем устройстве происходит в больиинстве случаев по влиянию окружной скорости барабана молотарки и зазора в молотильном барабане и подбарабанье. Так как зазор в молотильном пространстве может быть не постоянным и изменен с уменьшением со входа растительной массы $в$ молотильное устройство до его выхода. Как обобщающий параметр, при исследованиях использовали зазор в молотильном пространстве при выходе с молотилки. Таким образом исследования проводили, определив частоту вращуения барабана в $450 \mathrm{muн}^{-1}$. В результате исследований определили, что характерное влияние на потери и травмирование зерна имеет круговая скорость барабана. Так, при повышении частоты вращуения на 100 мин $^{-1}$ с 440 u до 540 мин $^{-1}$, потери и травмирование зерна увеличивались с 1,4\% до 5,4\%, то есть в 4 раза.

Ключевые слова: зерно, комбайн, потери, модель, сепараџия, устройство

\section{ANALYSIS OF LOSS OF GRAIN GRAINS BY CLASSICAL THRUSTING AND SEPARATING DEVICE OF GRAIN HARVESTER COMBINE}

\section{L. Rogovskii}

Abstract. Based on the analysis of most domestic combines, it is established that they have a traditional scheme of threshing and separating device, which includes one or two sequentially arranged threshing threshers and keyboard straw shaker. The design of drumming from rods with cross plates provides, first of all, intensification of process of threshed grain. Cereals are threshed easily, so there is no need to intensify threshing. For example, when harvesting grain harvester KZS-9M "Slavutich" with a gap at the outlet between the threshing drum and the drum $18 \mathrm{~mm}$ and the speed of the threshing drum $450 \mathrm{~min}^{-1}$, the loss of threshing was absent in all experiments. In this case, the transverse plates of the drum are an obstacle to the movement of the threshed mass in the threshing-separating device, forming a dead space behind each bar, where a small component of plant mass accumulates.

The quality of the threshing and separating device of the combine harvester was determined by the coefficients of undersmilling, separation, crushing and clogging of the grain received for cleaning. 
Роговський І. Л.

Damage to the grain during threshing in the thresher is mainly due to the influence of the circumferential linear velocity of the threshing drum and the gap between the threshing drum and the drum. Therefore, the gap in the threshing space is variable and changes in the direction of decrease from the entrance of the plant mass into the threshing device to its exit. To summarize, we used the gap in the threshing space at the outlet of the thresher. In this regard, the beginning of the tests was at a drum speed of $450 \mathrm{~min}^{-1}$. During the tests it was found that the greatest influence on the damage to the grain has a circular linear speed of the threshing drum. Thus, when increasing the speed of the drum per $100 \mathrm{~min}^{-1}$ from 450 to $550 \mathrm{~min}^{-1}$, the damage increased from $1.5 \%$ to $5.5 \%$, ie almost 4 times.

Key words: grain, combine, losses, model, separation, device 